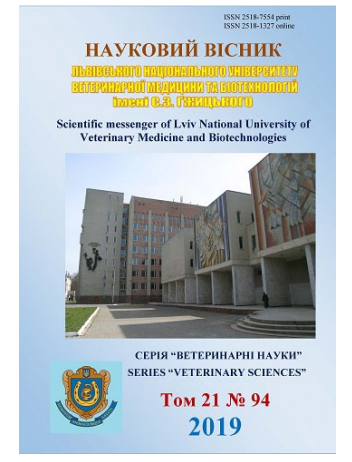

Науковий вісник Дьвівського національного університету ветеринарної медицини та біотехнологій імені С.3. Гжицького.

\author{
Серія: Ветеринарні науки
}

\section{Scientific Messenger of Lviv National University of Veterinary Medicine and Biotechnologies. Series: Veterinary sciences}

doi: $10.32718 /$ nvlvet 9418

http://nvlvet.com.ua

UDC 619.615.5

\title{
Acute and subacute toxicity of the drug based on tylosin tartrate
}

\author{
I.P. Patereha ${ }^{1}$, V.I. Kushnir ${ }^{1}$, M.I. Zhyla ${ }^{1}$, O.M. Dubin ${ }^{2}$ \\ ${ }^{1}$ State Scientific-Research Control Institute of Veterinary Medicinal Products and Feed Additives, Lviv, Ukraine \\ ${ }^{2}$ PSC “Technolog”, Uman, Ukraine
}

Article info

Received 11.04.2019

Received in revised form 13.05.2019

Accepted 14.05.2019

State Scientific-Research Control Institute of Veterinary Medicinal Products and Feed Additives 11, Donetska str., Lviv, 79019, Ukraine.

Tel.:+38-067-261-75-20

E-mail: ippater@ukr.net

PSC "Technolog",

Stara Prorizna Str., 8, Uman, Cherkassy region, 20300, Ukraine

Patereha, I.P., Kushnir, V.I., Zhyla, M.I., \& Dubin, O.M. (2019). Acute and subacute toxicity of the drug based on tylosin tartrate. Scientific Messenger of Lviv National University of Veterinary Medicine and Biotechnologies. Series: Veterinary sciences, 21(94), 97-102. doi: $10.32718 /$ nvlvet 9418

The article presents the results of a study of the acute and subacute toxicity of the drug TILOTAR ( $a$ water-soluble powder for oral administration) made on the basis of tylosin tartrate. As a result of the research it was found that the drug "TILOTAR" refers to the 4th class of toxicity, that is, to low-toxic substances. After intragastric administration of the drug to white mice and rats at doses of 2500, $5000,7500 \mathrm{mg} / \mathrm{kg}$, all animals remained alive. Short-term inhibition was recorded in laboratory animals, which were given the drug at the maximum dose. Further changes in the clinical state of the animals of the experimental groups were not observed. The study of subacute toxicity of the drug "TILOTAR" showed that 14-day administration of a therapeutic dose of the drug leads to a decrease in erythropoiesis, the appearance of old forms of erythrocytes, damage to hepatocytes, the appearance of eosinophils, $\gamma$ globulins, a decrease in protein biosynthesis, increased kidney function. The introduction of a 10-fold dose within 14 days reduced the body weight of the rats, leading to abnormalities in the liver and kidneys, and a decrease in the mass of the spleen. An increase in urea blood concentration and a decrease in creatinine may indicate impaired renal function in animals that were given a tenfold dose of the drug, and an increase in the level of $\alpha$ - and $\gamma$-globulins against the background of a decrease in body weight of rats indicates an overload of the body's immune system. In rats of the therapeutic group, homeostasis was maintained by enhancing kidney function, accompanied by a decrease in the number of erythrocytes due to young forms and the appearance of mature erythrocytes with a high level of hemoglobin (MCH), some destruction of hepatocytes (high level of alkaline phosphatase activity) while reducing the amount of albumin, an increase in relative levels of $\alpha$-and $\gamma$-globulins. In the conducted experiments it was established that the macroscopic and microscopic structure of the internal organs of rats, while studying the subacute toxicity of the drug "TILOTAR", was preserved, no macroscopic changes were revealed. In rats receiving a 10-fold therapeutic dose of the drug for 14 days, focal protein dystrophy of the liver and kidneys was histologically established.

Key words: tilotar, tylosin tartrate, acute toxicity, subacute toxicity, rats, mice, dose.

\section{Гостра і підгостра токсичність препарату на основі тилозину тартрату}

\author{
І.П. Патерега ${ }^{1}$, В.І. Кушнір ${ }^{1}$, М.І. Жила' ${ }^{1}$, О.М. Дубін ${ }^{2}$ \\ ${ }^{1}$ Державний науково-дослідний контрольний інститут ветеринарних препаратів та кормових добавок, \\ м. Львів, Україна \\ ${ }^{2} П р А Т$ “Технолог”, м. Умань, Черкаська обл., Україна
}

У статті наведені результати вивчення гострої та підгострої токсичності препарату “ТИЛОТАР” (водорозчинний порошок для перорального застосування), виготовленого на основі тилозину тартрату. У результаті проведених досліджень було встановлено, щцо препарат “ТИЛОТАР” належить до 4-го класу токсичності, тобто до малотоксичних речовин. Після внутрішньошлункового введення препарату білим мишам і шурам в дозах 2500, 5000, 7500 мг/кг всі тварини залишалися жсивим. Короткочасне пригні- 
чення фіксували у лабораторних тварин, яким задавали препарат у максимальній дозі. В подальшому змін в клінічному стані тварин дослідних груп не спостерігали. Вивчення підгострої токсичності препарату “ТИЛОТАР” показало, щяо 14-добове введення терапевтичної дози препарату призводить до зменшення еритропоезу, появи старих форм еритроцитів, порушення гепатоцитів, появи еозинофілів, ү-глобулінів, зниження біосинтезу білка, посилення роботи нирок. Введення протягом 14-діб 10-кратної дози препарату знижувало масу тіла щурів, приводило до порушень з боку печінки і нирок, зниження маси селезінки. Підвищення концентрації в крові сечовини та зниження креатиніну може вказувати на порушення функиї нирок у тварин, яким задавали десятикратну дозу препарату, а збільшення рівня $\alpha$ - $i$-глобулінів на тлі зменшення ваги тіла шурів свідчить про перевантаження імунної системи організму. У цурів терапевтичної групи гомеостаз підтримувався за рахунок посилення роботи нирок, ицо супроводжувалося зменшенням кількості еритроцитів за рахунок молодих форм і появою зрілих еритроцитів з вищим рівнем гемоглобіну (МСН), деякої деструкції гепатоцитів (високий рівень активності лужної фосфатази) на тлі зниження кількості альбумінів, підвищення відносного рівня $\alpha$ - $i$ ү-глобулінів. В проведених дослідах встановлено, шзо макроскопічна та мікроскопічна структура внутрішніх органів щурів, за вивчення підгострої токсичності препарату “ТИЛОТАР” збережена, макроскопічних змін не виявлено. У щурів, які отримували 10-кратну терапевтичну дозу препарату впродовж 14 діб, гістологічно встановлено вогнищеву білкову дистрофію печінки та нирок.

Ключові слова: тилотар, тилозину тартрат, гостра і підгостра токсичність, щуррі, мищі, доза.

\section{Вступ}

Антибіотики нині є одними із найбільш поширених лікарських препаратів (Halatiuk et al., 2010; Kotsiumbas et al., 2014). При цьому практика їх застосування рясніє прикладами нераціонального і малоефективного призначення, які можна пояснити недостатнім знанням їх властивостей, токсичності та методів застосування.

Зі значного арсеналу використовуваних у тваринництві антибіотиків, препарати тилозину останнім часом набули широкого застосування у ветеринарній практиці.

Одним із перших етапів фармакологічного дослідження ветеринарних препаратів $\epsilon$ встановлення токсичності (SOU 85.2-37-736:2011; Gutyj et al., 2018; Todoriuk et al., 2018), тому метою нашої роботи було вивчення гострої та підгострої токсичності препарату на основі тилозину тартрату.

\section{Матеріал і методи досліджень}

Дослідження проводили відповідно·з методичними рекомендаціями “Токсикологічний контроль нових засобів захисту тварин” і “Доклінічні дослідження ветеринарних лікарських засобів” (Kosenko et al., 1997; Litvinova et al., 2001; Kotsiumbas et al., 2006).

Параметри гострої токсичності препарату “ТИЛОТАР" досліджували на 30 білих мишах 2-3місячного віку, масою 19-22 г та 30 білих щурах, віком 2-3 місяці, масою 180-200 г. Препарат вводили внутрішньошлунково, одноразово, попередньо розчинивши у воді.

Для встановлення токсичності препарату “ТИЛОТАР” для білих мишей і білих щурів було застосовано дози: 2500, 5000 та 7500 мг/кг на тварину. На кожну дозу було використано по 6 лабораторних тварин.

Дозу 7500 мг/кг маси тіла тварини було введено повторно на подвійній кількості тварин.

Після введення препарату спостереження за лабораторними тваринами вели протягом 14 діб. При цьому враховували такі показники: зовнішній вигляд, поведінку тварин, стан шерсті, видимих слизових оболонок, ставлення до корму, ритм, частоту дихан- ня, час виникнення та характер інтоксикації, пї важкість, перебіг, час загибелі тварин або їх одужання.

Підгостру токсичність вивчали на 18 білих щурах масою 180-200 г. Було сформовано 3 однакові за кількістю та масою групи, по 6 щурів кожна. I група тварин була контрольною. Їм вводили воду. Тваринам інших двох груп вводили внутрішньошлунково щоденно ТИЛОТАР у дозах: II група - терапевтична 1,0 мг/кг маси тіла, та III група - десятикратна терапевтична - 10,0 мг/кг маси тіла. У підгострому досліді ТИЛОТАР вводили щурам протягом 14 діб. Упродовж досліду проводили спостереження за клінічним станом та поведінкою тварин.

На наступну добу від часу закінчення введення препарату лабораторних тварин за умов легкого ефірного наркозу декапітували, відбирали проби крові, проводили гематологічні і біохімічні дослідження за загальновизнаними методиками та розтинали і визначали масу органів порівняно 3 контрольною групою. Тварин зважували на початку і в кінці досліду, вираховували коефіцієнти маси внутрішніх органів.

Для гематологічних досліджень використовували кров стабілізовану ЕДТА, а для біохімічних досліджень - сироватку крові. В стабілізованій крові визначали: вміст гемоглобіну, кількість еритроцитів i лейкоцитів, лейкограму, гематокрит, індекси червоної крові - за допомогою гематологічного аналізатора Mythic-18. У сироватці крові визначали: загальний білок за допомогою рефрактометра ІРФ-22, активність ензимів (АлАТ, АсАТ, ЛФ), вміст креатиніну, сечовини за допомогою напівавтоматичного біохімічного аналізатора HumaLyzer 3000 з використанням стандартних наборів фірми Human. Фракційний склад білків (альбуміни, $\alpha 1$-, $\alpha 2-, \beta$ - і $\gamma$-глобуліни) сироватки крові визначали методом електрофорезу на ацетаті целюлози за допомогою приладу для мікрозонального електрофорезу Scan Power 300 та Scanion Lira 400, Hospitex Diagnostics.

Матеріал для гістологічного дослідження фіксували в 10\% нейтральному розчині формаліну з подальшою заливкою в парафін (Merkulov, 1969). Гістозрізи виготовляли на санному мікротомі МС-2, фарбували гематоксиліном та еозином. Мікроскопію проводили 3 допомогою мікроскопа OLIMPUS CX-41. 


\section{Результати та їх обговорення}

Встановлено, що після введення препарату в дозах 2500, 5000, 7500 мг/кг всі тварини залишалися живими. Короткочасне пригнічення константували у лабораторних тварин, яким задавали препарат у максимальній дозі. В подальшому змін в клінічному стані тварин дослідних груп не спостерігали.

Встановлено, що препарат “ТИЛОТАР” належить до малотоксичних речовин - 4 клас згідно зі СОУ 85.2-37-736:2011. ЛД50 за його внутрішньошлункового введення лабораторним тваринам (білі миші та щури) є більшою за 7500 мг/кг.
При проведенні досліду з вивчення підгострої токсичності загибелі лабораторних щурів не встановлено.

Аналіз отриманих результатів після 14-добового застосування препарату “ТИЛОТАР” показує, що десятикратна доза препарату приводила до вірогідного зниження живої маси тіла і коефіцієнтів маси селезінки у білих щурів, у тварин терапевтичної групи правої нирки (табл. 1); а у двох дослідних групах проявляється тенденція до підвищення рівня еозинофілів (табл. 2) та статистично збільшувався середній вміст гемоглобіну в еритроциті (MCH).

\section{Таблиця 1}

Коефіцієнти маси внутрішніх органів білих щурів на 14-ту добу за вивчення підгострої токсичності препарату “ТИЛОТАР” (M $\pm \mathrm{m}, \mathrm{n}=6)$

\begin{tabular}{lccc}
\hline \multirow{2}{*}{ Внутрішні органи } & \multicolumn{3}{c}{ Групи тварин } \\
\cline { 2 - 4 } & Контрольна & 1 група & 2 група \\
Печінка & $33,4 \pm 1,02$ & $33,03 \pm 0,96$ & $3,8 \pm 1,9$ \\
Нирка права & $3,57 \pm 0,1$ & $3,23 \pm 0,11^{*}$ & $3,3 \pm 0,18$ \\
Нирка ліва & $3,3 \pm 0,11$ & $3,07 \pm 0,1$ & $3,13 \pm 0,16^{*}$ \\
Селезінка & $4,3 \pm 0,36$ & $4,22 \pm 0,3$ & $3,28 \pm 0,09$ \\
Серце & $3,6 \pm 0,1$ & $3,43 \pm 0,18$ & $8,31 \pm 0,53$ \\
Легені & $8,08 \pm 0,3$ & $9,48 \pm 1,05$ & $178,0 \pm 2,13 * * *$ \\
Маса & $216,3 \pm 3,4$ & $206,0 \pm 6,0$ &
\end{tabular}

\section{Таблиця 2}

Морфологічні показники крові білих щурів на 14-ту добу тривалого досліду за вивчення підгострої токсичності препарату $(\mathrm{M} \pm \mathrm{m}, \mathrm{n}=6)$

\begin{tabular}{lccc}
\hline \multicolumn{1}{c}{ Показники } & Контрольна група & 1 група & 2 група \\
\hline Гемоглобін, г/л & $151,5 \pm 2,5$ & $148,4 \pm 2,6$ & $152,5 \pm 5,0$ \\
Еритроцити, Т/л & $6,8 \pm 0,09$ & $6,4 \pm 0,1^{*}$ & $6,5 \pm 0,2$ \\
Лейкоцити, Г/л & $15,8 \pm 1,5$ & $16,8 \pm 1,9$ & $13,5 \pm 0,6$ \\
Еозинофіли, \% & $0,8 \pm 0,4$ & $2,5 \pm 0,5^{*}$ & $3,0 \pm 0,6^{*}$ \\
Нейтрофіли, \% & $18,4 \pm 1,2$ & $19,2 \pm 1,4$ & $20,5 \pm 1,0$ \\
Лімфоцити, \% & $74,0 \pm 0,5$ & $70,8 \pm 1,4$ & $70,0 \pm 0,8$ \\
Моноцити, \% & $6,8 \pm 0,5$ & $7,6 \pm 0,4$ & $6,5 \pm 0,5$ \\
Гематокрит, \% & $39,0 \pm 1,5$ & $38,4 \pm 0,7$ & $39,6 \pm 1,2$ \\
МСН, пг & $22,2 \pm 0,2$ & $23,3 \pm 0,4^{*}$ & $23,4 \pm 0,8^{*}$ \\
МСНС, г/дл & $38,0 \pm 0,3$ & $38,7 \pm 0,3$ & $38,5 \pm 0,2$ \\
МСV, мкм & $58,4 \pm 0,6$ & $60,4 \pm 1,1$ & $60,6 \pm 1,6$ \\
\hline
\end{tabular}

Примітка: * $-\mathrm{P}<0,05$

За умов застосування терапевтичної дози препарату в сироватці крові відзначено збільшення активності лужної фосфатази, рівня $\alpha$ - i $\gamma$ - глобулінів і зниження концентрації альбумінів (табл. 3). 14-добове застосування 10-кратної дози препарату приводило до збільшення рівня сечовини і зменшення рівня креатиніну.

Підвищення концентрації в крові сечовини та зниження креатиніну може вказувати на порушення функції нирок у тварин, яким задавали десятикратну дозу препарату, а збільшення рівня $\alpha$ - і $\gamma$-глобулінів на тлі зменшення ваги тіла щурів свідчить про перевантаження імунної системи організму.

У щурів терапевтичної групи гомеостаз підтримувався за рахунок посилення роботи нирок, що супро- воджувалося зменшенням кількості еритроцитів за рахунок молодих форм і появою зрілих еритроцитів 3 вищим рівнем гемоглобіну (MCH), деякої деструкції гепатоцитів (високий рівень активності лужної фосфатази) на тлі зниження кількості альбумінів, підвищення відносного рівня $\alpha$ - і $\gamma$-глобулінів.

При патологоанатомічному розтині макроскопічних змін у внутрішніх органах, на слизових, серозних покривах у щурів контрольної та дослідних груп не виявляли, розміщення внутрішніх органів анатомічно правильне, очеревина та костальна плевра гладка, блискуча, волога, без нашарувань. Серце конусоподібної форми, перикадр прозорий без нашарувань, міокард - пружної консистенції червоного кольору. 
Таблиця 3

Біохімічні показники крові білих щурів на 14-ту добу досліду при вивченні підгострої токсичності препарату “ТИЛОТАР” $(\mathrm{M} \pm \mathrm{m}, \mathrm{n}=6)$

\begin{tabular}{|c|c|c|c|c|}
\hline Показники & & Контрольна & 1 група & 2 група \\
\hline АлАТ, Од./л & & $92,43 \pm 3,26$ & $83,7 \pm 0,95$ & $93,7 \pm 2,82$ \\
\hline АсАТ, Од./л & & $208,87 \pm 19,34$ & $215,73 \pm 17,32$ & $205,1 \pm 13,42$ \\
\hline ЛФ, Од./л & & $214,97 \pm 1,72$ & $303,13 \pm 23,52 *$ & $252,0 \pm 47,35$ \\
\hline Креатинін, ммоль/л & & $70,9 \pm 1,57$ & $65,8 \pm 3,64$ & $64,9 \pm 1,03^{*}$ \\
\hline Сечовина, ммоль/л & & $5,13 \pm 0,10$ & $5,65 \pm 0,4$ & $6,65 \pm 0,20 * * *$ \\
\hline Протеїн загальний, г/л & & $78,7 \pm 2,32$ & $74,4 \pm 0,9$ & $76,7 \pm 1,23$ \\
\hline Альбуміни, \% & & $53,85 \pm 0,68$ & $44,8 \pm 1,89 * *$ & $55,5 \pm 1,96$ \\
\hline \multirow{4}{*}{ Глобуліни, \% } & $\alpha 1$ & $4,98 \pm 0,63$ & $6,78 \pm 0,23 *$ & $5,66 \pm 0,64$ \\
\hline & $\alpha 2$ & $3,85 \pm 0,06$ & $6,96 \pm 0,84^{*}$ & $4,74 \pm 0,75$ \\
\hline & $\beta$ & $21,2 \pm 0,63$ & $21,06 \pm 1,31$ & $18,82 \pm 0,91$ \\
\hline & $\gamma$ & $16,1 \pm 0,77$ & $20,4 \pm 1,1 * *$ & $15,3 \pm 1,0$ \\
\hline
\end{tabular}

Примітка: *-P <0,05, **-P <0,01***-P<0,001

Легені блідо-рожевого кольору, пухкої консистенції, поділ на окремі долі добре виражений, плевра без нашарувань та крововиливів. Шлунок, тонкі кишки заповнені кормовими масами, товстий кишечник сформованими каловими масами, слизова оболонка блідо-рожева, блискуча, волога, без нашарувань. Печінка темно-червоного кольору, капсула гладка, не збільшена, краї гострі, рівномірно кровонаповнена, із характерною структурою на розрізі, пружної консистенції. У щурів, яким вводили 10-кратну дозу препарату "Тилотар", виявляли вогнища світлокоричневого кольору, рихлої консистенції. Нирки бобовоподібні, темно-червоного кольору, не збільшені, межа між кірковою і мозковою зонами збережена, капсула знімається легко. Селезінка темно-вишневого кольору, не збільшена, краї гострі, на розрізі структура збережена. Підшлункова залоза часточкової будови, пружної консистенції, світло-рожевого кольору.

Гістологічна структура печінки щурів усіх досліджуваних груп збережена. У більшості щурів, які отримували 10-кратну терапевтичну дозу препарату впродовж 14 діб, виявляли помірну дискомплексацію пластинчатої будови часточок. Центральні вени часточок розширені, кровонаповнені, наявні вогнища гепатоцитів 3 неоднорідною, зернистою, слабозабарвленою цитоплазмою із гітрофованими ядрами (рис. 13).

Міокард щурів як контрольної, так і дослідних груп представлений пучками м'язових волокон, із збереженою поперечною посмугованістю, ядра кардіоміоцитів розміщені ексцентрично. При гістологічній оцінці структури нирок дистрофічні зміни переважно білкового характеру, виявляли в щурів, яким застосовували 10-кратну терапевтичну дозу препарату “Тилотар" впродовж 14 діб (рис. 4).

Гістологічна структура селезінки збережена у всіх досліджуваних групах тварин. Поділ на червону та білу пульпу збережений. Червона пульпа помірно кровонаповнена, біла пульпа представлена переважно

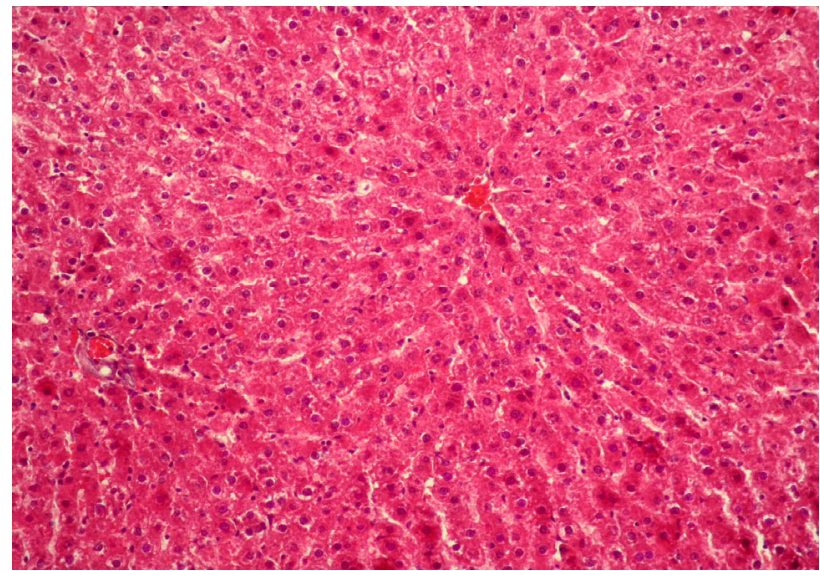

Рис. 1. Гістологічна структура печінки щура 2 групи (10-кратна доза). Радіальне розміщення гепатоцитів збережене, центральні вени часточок помірно розширені, кровонаповнені. Гематоксилін та еозин. Ок. 10, об. 20

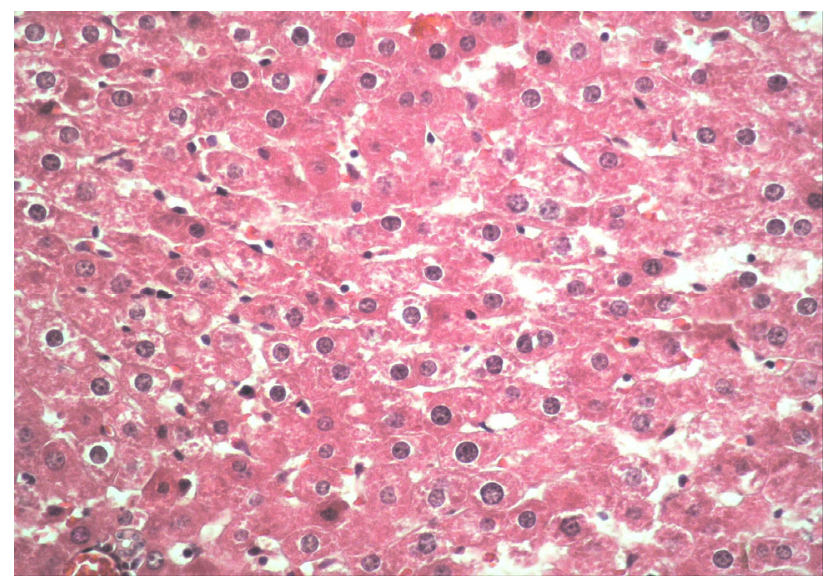

Рис. 2. Печінка щура 2 дослідної групи на 14 добу. Цитоплазма гепатоцитів неоднорідно забарвлена, зерниста, ядра гіпертрофовані. Гематоксилін та еозин. Ок. 10 , об. 40 первинними лімфоїдними вузликами округлої форми. Вузлики добре заселені клітинами лімфоїдного ряду, реактивні центри зустрічалися рідко (рис. 5-6). 


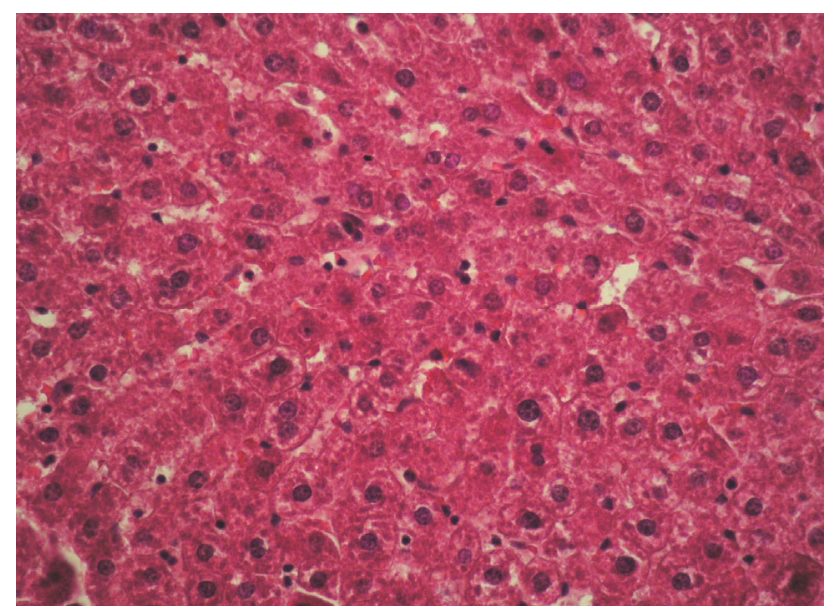

Рис. 3. Печінка щура 1 дослідної групи на 14 добу. Гепатоцити чітко контуровані, цитоплазма добре забарвлена, переважно однорідна. Гематоксилін та еозин. Ок. 10, об. 40

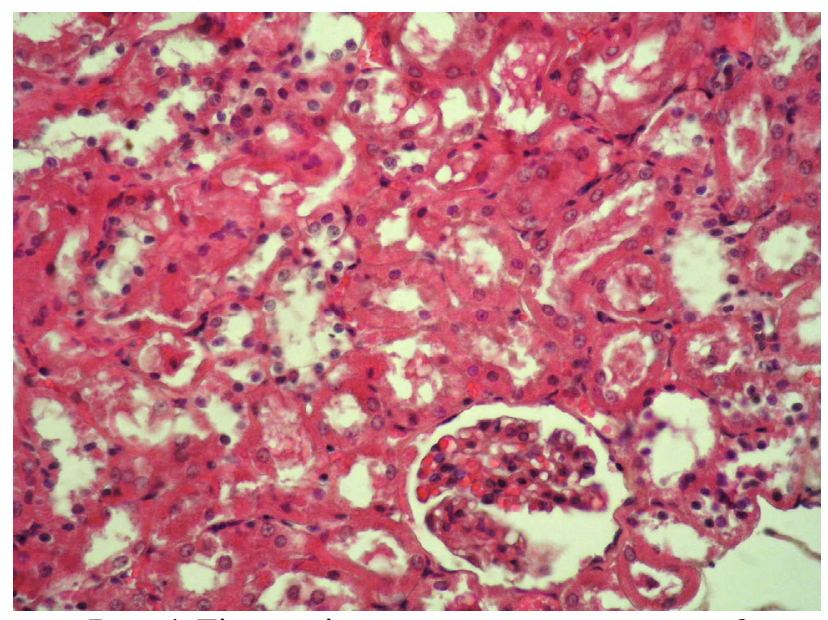

Рис. 4. Гістологічна структура нирки щура 2 дослідної групи на 14 добу. Гематоксилін та еозин. Ок. 10 , об. 20

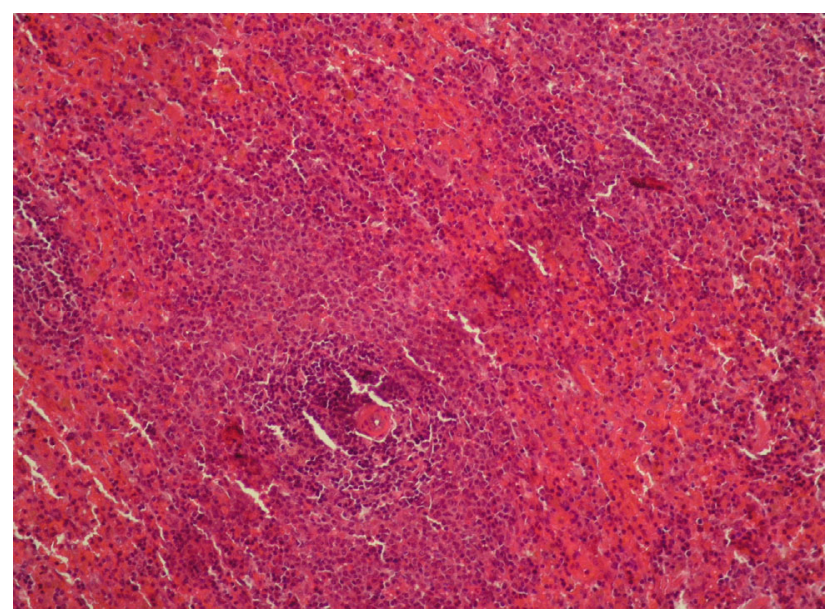

Рис. 5. Гістоструктура селезінки щура 2 дослідної групи на 14 добу. Поділ на червону і білу пульпу збережений. Гематоксилін та еозин. Ок. 10, об. 10

Макроскопічна та мікроскопічна структура внутрішніх органів щурів, за вивчення підгострої токсичності препарату “ТИЛОТАР” збережена, макроскопі- чних змін не виявлено. У щурів, які отримували 10кратну терапевтичну дозу препарату впродовж 14 діб, гістологічно встановлено вогнищеву білкову дистрофію печінки та нирок.

Аналіз гістроструктури селезінки та їі лімфатичного вузлика може вказувати на їх структурну незмінність, а зниження маси селезінки підтверджує думку, що це є наслідком зменшення іiї депо.

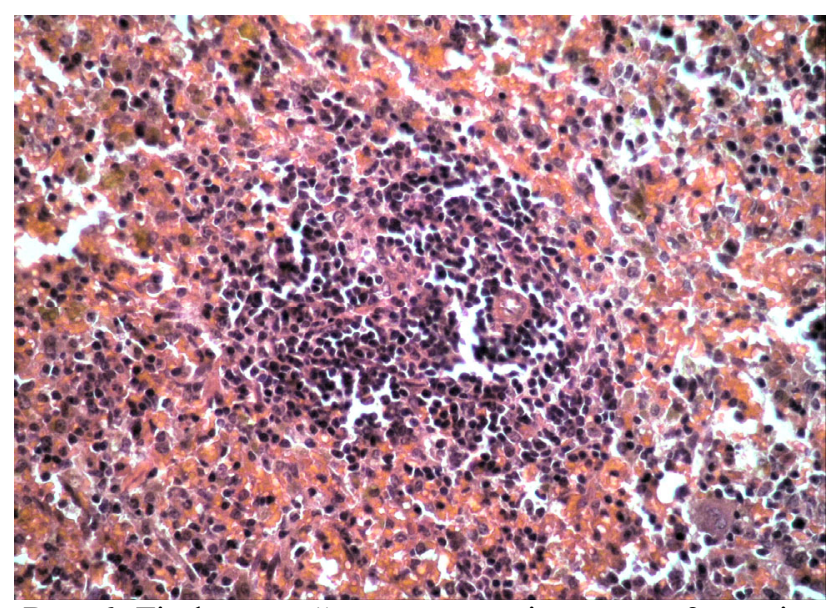

Рис. 6. Лімфатичний вузлик селезінки щура 2 дослідної групи. Гематоксилін та еозин. Ок. 10, об. 20

Отже, макроскопічна та мікроскопічна структура внутрішніх органів щурів збережена, макроскопічних змін не виявлено. У щурів, які отримували 10-кратну терапевтичну дозу препарату впродовж 14 діб, гістологічно встановлено вогнищеву білкову дистрофію печінки та нирок.

\section{Висновки}

1. Препарат “ТИЛОТАР” належить до 4-го класу токсичності, тобто до малотоксичних речовин.

2 14-добове введення терапевтичної дози препарату призводить до зменшення еритропоезу, появи старих форм еритроцитів, порушення гепатоцитів, появи еозинофілів, $\gamma$-глобулінів, зниження біосинтезу білку, посилення роботи нирок.

3. Введення протягом 14 діб 10-кратної дози препарату знижувало масу тіла щурів, приводило до порушень з боку печінки і нирок, зниження маси селезінки.

4. В проведених дослідах встановлено, що макроскопічна та мікроскопічна структура внутрішніх органів щурів за вивчення підгострої токсичності препарату “ТИЛОТАР” збережена, макроскопічних змін не виявлено. У щурів, які отримували 10-кратну терапевтичну дозу препарату впродовж 14 діб, гістологічно встановлено вогнищеву білкову дистрофію печінки та нирок.

Перспективи подальших досліджень. Результати досліджень будуть використані для контролю якості препарату за показником “нешкідливісь”. 


\section{References}

Gutyj, B., Grymak, Y., Hunchak, V., Mysak, A., Nazaruk, N., Brezvyn, O., Hariv, I., Shcherbatyy, A., Semeniv, B., Bushueva, I., Parchenko, V., \& Kaplaushenko, A. (2018). Preclinical searches of the preparation Thireomagnile. Ukrainian Journal of Ecology, 8(1), 688-695. doi: 10.15421/2018_267.

Halatiuk, O.Ye. Solodka, L.O., Rybachuk, Zh.V., \& Yakymchuk, T.S. (2010). Zastosuvannia antybiotykiv pry respiratornykh zakhvoriuvanniakh molodniaku VRKh. Veterynarna medytsyna, 93, 91-94. Rezhym dostupu: http://nbuv.gov.ua/UJRN/vetmed_2010_93_20 (in Ukrainian).

Kosenko, M.V., Malyk, O.H., \& Kotsiumbas, I.Ia. (1997). Toksykolohichnyi kontrol novykh zasobiv zakhystu tvaryn: Metodychni rekomendatsii. K. (in Ukrainian).

Kotsiumbas I.Ya., Malyk O.H., \& Patereha I.P. (2006). Doklinichni doslidzhennia veterynarnykh likarskykh zasobiv. Za red. I.Ia. Kotsiumbasa. Lviv: Triada plius (in Ukrainian).
Kotsiumbas, I.Ya., Muzyka, V.P., \& Stetsko, T.I. (2014). Stan antybiotykorezystentnosti mikroorhanizmiv zbudnykiv bakterialnykh zakhvoriuvan molodniaku velykoi rohatoi khudoby i svynei Naukovyi visnyk veterynarnoi medytsyny, 13, 117-120. Rezhym dostupu:http://nbuv.gov.ua/UJRN/nvvm_2014_13_36 (in Ukrainian).

Litvinova, N.V., Filonenko-Patrusheva, M.A., Frantsuzova, S.B., \& Khrapak, V.V. (2001). Doklinichni doslidzhennia likarskykh zasobiv: Metodychni rekomendatsii. K.:Avitsenna (in Ukrainian).

Merkulov, G.A. (1969). Kurs patologogistologicheskoj tehniki. L.: Medicina (in Russian).

SOU 85.2-37-736:2011 (2011). Preparaty veterynarni. Vyznachannia hostroi toksychnosti. K: Minahropolityky (in Ukrainian).

Todoriuk, V.B., Hunchak, V.M., Gutyj, B.V., Gufriy, D.F., Hariv, I.I., Khomyk, R.I. , \& Vasiv, R.O. (2018). Preclinical research of the experimental preparation "Ferosel T". Ukrainian Journal of Veterinary and Agricultural Sciences, 1(1), 3-9. doi: 10.32718/ujvas1-1.01. 